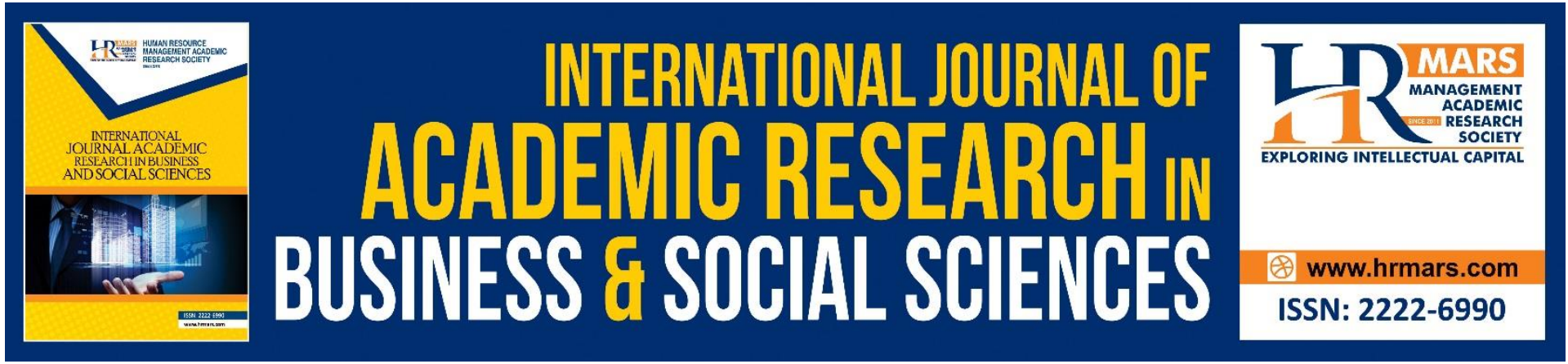

\title{
The Effect of Teluk Anson Wharf Development on Urbanization in Lower Perak, 1900-1957
}

Khairi Ariffin, Mohd Hairy Ibrahim, Mohd Kamal Kamarudin, Sahul Hamid Mohamed Maiddin, Ganesan Shanmugavelu, Siti Zaharah Mahfood, Wan Norlizawati Wan Mat Ali, Bipin Babulal, Tuan Waheda Tuan Chik

To Link this Article: http://dx.doi.org/10.6007/IJARBSS/v11-i7/10520 DOI:10.6007/IJARBSS/v11-i7/10520

Received: 17 May 2021, Revised: 24 June 2021, Accepted: 13 July 2021

Published Online: 25 July 2021

In-Text Citation: (Ariffin et al., 2021)

To Cite this Article: Ariffin, K., Ibrahim, M. H., Kamarudin, M. K., Maiddin, S. H. M., Shanmugavelu, G., Mahfood, S. Z., Ali, W. N. W. M., Babulal, B., \& Chik, T. W. T. (2021). The Effect of Teluk Anson Wharf Development on Urbanization in Lower Perak, 1900-1957. International Journal of Academic Research in Business and Social Sciences, 11(7), 626-636.

Copyright: (c) 2021 The Author(s)

Published by Human Resource Management Academic Research Society (www.hrmars.com)

This article is published under the Creative Commons Attribution (CC BY 4.0) license. Anyone may reproduce, distribute, translate and create derivative works of this article (for both commercial and non-commercial purposes), subject to full attribution to the original publication and authors. The full terms of this license may be seen at: http://creativecommons.org/licences/by/4.0/legalcode

Vol. 11, No. 7, 2021, Pg. 626 - 636

Full Terms \& Conditions of access and use can be found at http://hrmars.com/index.php/pages/detail/publication-ethics 


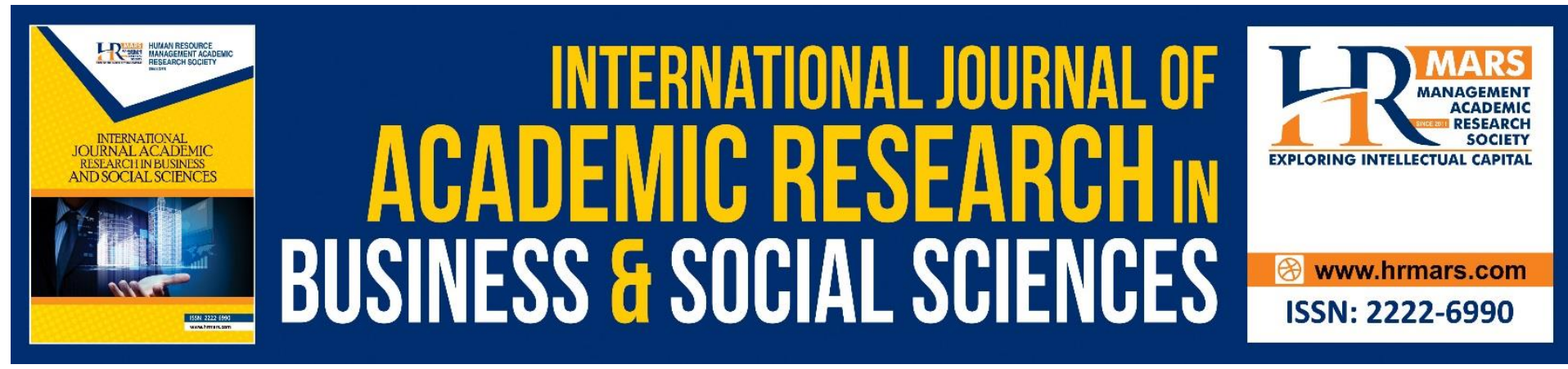

\title{
The Effect of Teluk Anson Wharf Development on Urbanization in Lower Perak, 1900-1957
}

\author{
Khairi Ariffin, Mohd Hairy Ibrahim, Mohd Kamal Kamarudin, \\ Sahul Hamid Mohamed Maiddin, Ganesan Shanmugavelu, Siti \\ Zaharah Mahfood, Wan Norlizawati Wan Mat Ali, Bipin Babulal, \\ Tuan Waheda Tuan Chik \\ Department of History, Faculty of Human Science, Sultan Idris Education University, \\ 35900 Tanjung Malim Perak, Malaysia
}

\begin{abstract}
Teluk Anson has one of the most important wharves in the Federated Malay States. Teluk Anson wharf also became the attraction to the ships sailing from other states in Malaya, South East Asia, Europe, and America. Its role as the main wharf became so significant to the extent it became one of the main and important wharves in the Federated Malay States besides Port Weld and Port Swettenham, which consequently influenced the development in Lower Perak. This study totally used the qualitative method which emphasized the analysis of documents and manuscripts. Critical observation and analysis of records or documents used were very important to obtain accurate data. The result shows that the existence of the wharf had caused the development of the railway system, commercial agriculture, and improvement of the irrigation system. Thus, it stimulated development in Lower Perak district into a distinguishable town in Perak.
\end{abstract}

Keywords: Wharf, Teluk Anson, Development of Urbanization, Lower Perak

\section{Introduction}

The British colonial administration in Perak since 1874 created various aspects of the new trade economy. This included the British effort in the establishment of an important wharf that became the center of maritime trade activity. The construction of wharves was after European colonization since Portuguese administration in Malacca till it expanded to other states in Tanah Melayu which included during British administration in Perak. Before the arrival of British colonial, the sea in Tanah Melayu which was in the South China Sea and Malacca Straits had become the main maritime-based trade route. Besides, the South China Sea and Malacca Straits were the main communication route for southeast Asians and also the trade route between India and China.

One of the most important wharves in the Federated Malay States was in Teluk Anson. Teluk Anson which was a town and also a wharf had been categorized as a developed area in a short period. This was acknowledged by Sir Frederic Aloysius Weld whose role was the Governor of the Strait States from 1880 until 1887. Such observation was based on his visiting experience and short encounter with Mr. Denison, the Superintendent of Lower Perak, and also with a 
Malay officer. Teluk Anson was also addressed as a prosperous and developing town though initially the area was filled with thick forest. On another note, Teluk Anson town also served as an important train station terminal in Lower Perak which also functioned as an attractive place and assembly of agricultural and mining yields for districts bordering Lower Perak. This activity caused the town to become a trade center that utilized train services for delivering trade goods such as tin ores and rubber.Teluk Anson was known as a wharf during the British administration era since its opening in 1882.

In 1896, the Teluk Anson wharf was placed under maintenance and entrusted under Federated Malay States Railways (FMSR). The development and construction of the Teluk Anson wharf were very important as a wharf handled the import and export of mining and agricultural yields in Lower Perak. Lower Perak comprised of a number of towns and subdistrict regions which were Teluk Anson, Bagan Datoh, Batak Rabit, Chikus, Degong, Langkap, Selekoh, Simpang Tiga, Rungkup, Sungai Sumun, Hutan Melintang, Changkat Jong, Sungai Manik and Labu Kubong (Perak Secretariat 3277/1948, 1948). In addition to these areas, the Teluk Anson wharf was also being used by other districts bordering Lower Perak. This wharf also became the center of local traders. Before its construction in Sungai Perak, previously, the businessmen, traders, and peasants used Kuala Sungai Bidor as the wharf.

Teluk Anson wharf also became the attraction to the ships sailing from other states in Malaya, South East Asia, Europe, and America. Its role as the main wharf had become significant and crucial until it became one of the main and important wharves in the Federated Malay States apart from Port Weld and Port Swettenham. This wharf, however, was then moved from the initial site to the newer one which was one mile away downstream to overcome erosion problems, and more facilities, as well as logistics, were enhanced to provide better service for trades.

\section{Problem Statement}

The development and construction of the Teluk Anson wharf were very important as it was the one that managed the import and export of minerals and agricultural yields in Perak especially as the assembly center of tin ores and agricultural yields in Lower Perak. Besides, other districts bordering Lower Perak also used the Teluk Anson wharf facility. The wharf also became an attraction for local businessmen that previously used Kuala Sungai Bidor as the wharf prior to the construction of the wharf Teluk Anson in Sungai Perak.

Teluk Anson wharf also became an attraction for the merchant's vessels sailed from other states in Tanah Melayu, South East Asia, Europe, and America. Its role as the main wharf became so significant to the extent it became one of the main and important wharves in the Federated Malay States besides Port Weld and Port Swettenham, which consequently influenced the development in Lower Perak. Local socioeconomy concurrently changed along as per the increment in variety of commercial activities.

\section{Literature Review}

Prior to the existence of Federated Malay States, wharfs had an important role in the economy and trades in coastal regions and also involving traders from other countries. Hussin in his writing A Tale of Two Colonial Port-Towns in the Straits of Melaka: Dutch Melaka and English Penang (Hussin, 2002) explained the comparison between Malacca port during the Dutch colonization and Penang port during British occupation in the state. Properties of port towns featuring Dutch and British colonial in Malacca and Penang were described as well in the study. Both port towns were said to possess west-oriented elements and surroundings, 
like, having fort and church buildings. The study however concentrated more on the development of towns in Malacca and Penang ports during the Dutch and British colonization era. Trades and port development were only described in basis and general.

In general, Hussin's writing was much broader and holistic as compared to this study which focused more on the importance of Teluk Anson wharf and the trade activity via various shipping companies. Still, Hussin's study just now had illustrated the situation of town development as the consequence of the main port acivities in Malacca and Penang, and so, helping this study in figuring the importance of wharves or ports in Malay states in general. Therefore, the study conducted here would concentrate more on the main wharves in the Federated Malay States as well as their development during the British colonial era.

Wharf's purpose was also elaborated by Wayte in the article titled Port Weld (Wayte, 1959). This article emphasized the history of Port Weld's development and role since early of its opening in 1885. At the beginning of its establishment, Port Weld or Kuala Sepetang wharf served as the assembly place for tin ores yielded from Taiping, Kamunting, and Larut. However, the study only concentrated on the role and development of Port Weld without explaining other wharfs present in the Federated Malay States. Despite this, this article by Wayte provided an early picture concerning the importance of Port Weld and assisted in gathering information related to the history of the significant wharf establishment in Perak. Although this writing was more on the history and development of Port Weld, the whole figure related to the role of a wharf as the trade and ship anchored center contributed to identifying the importance of Teluk Anson wharf.

The Wharf activity in East Coast of Tanah Melayu was explained in article by Samsudin et al, where in their writing entitled Perkembangan Pengangkutan Marin Sekitar Pantai Timur Tanah Melayu Zaman Tradisional dan Zaman Pentadbiran British (Samsudin, Manaf \& Shaharudin, 2011). In the study, the authors' focus was mainly on the development and wharf activity in Pulau Tioman, Pekan, and Kuala Terengganu that became the stop center for the traditional trade ships during the British administration era. In addition, the article emphasized that Maritim and wharf activity continuously had expanded from the traditional era until the British colonial time. Even though the discussion mainly concerned with the development of wharves on the East Coast, it somewhat assisted in illustrating the relationship between British administration policy and the function of the wharf as the trade center.

The Writing entitled Teluk Anson: 1882-1941: Port, Agriculture, and Erosion (Khoo, 1995) were mainly about the background of Teluk Anson town which had an important role as the wharf as well as an agricultural region. The role and development of the Teluk Anson wharf were described on a basis and mostly concentrated on the erosion problem occurring in the Teluk Anson wharf. Besides, the study was mainly about the development of agriculture and main crops in Lower Perak district and Teluk Anson town. Nevertheless, an explanation of agricultural development that occurred at the place reflected that the role of the wharf was parallel to the development of agriculture as the crop yields were assembled in the Teluk Anson wharf before being exported. This writing also portrayed that crop yields were one of the important import and export products in Teluk Anson.

\section{Research Methodology}

This study totally used the qualitative method which emphasized the analysis of documents and manuscripts. Critical observation and analysis of records or documents used were very important to obtain accurate data. Official documents used in this study included from British 
colonials such as Perak Annual Report, Government Gazette, and Perak Secretariat File obtained from Malaysia National Archive. Secondary resources such as books, journals, and academic studies related to the development of wharves in Malay states were used as well to strengthen the study result.

\section{Findings}

The idea and concept of the town began from Ebenezer Howard that explained the new principle and concept related to a town in 1898 and the idea continued to expand afterward (Bakar, 1996). The word 'town' had various definitions. But in general, a town was defined as the center of administration, business, culture, and others. Geographical location, population size, occupation mode, and economic activity also influenced the true definition of a town. It was also interpreted as a gazetted area and densely built bordering region, and the combination of the population in both areas measured 10,000 and above (Rancangan Malaysia Ketujuh, 1996). Regardless, there was also different interpretation and opinion regarding the definition of a town. According to Hirschman, no standard definition of the minimum size for a certain town area in the context of Malaysia (Hirchman \& Yeoh, 1979). Urbanization pattern analysis in census report, government records, and through social study also prone to use different characteristics and population size in classifying a town region. Teluk Anson's development plan executed by Lieutenant Colonel Archibald Anson since 1879 had become the starting point to the emergence of Teluk Anson as a renowned town in Lower Perak. One of the early development planned carried out by Archibald Anson was developing a wharf in Teluk Anson, building a railway specifically for passengers and trade cargos, and developing an irrigation system for agriculture (Khoo, 1995). Through the plan, Teluk Anson became the pioneer in functioning as a wharf town in Lower Perak and one of the important wharves in Perak itself. According to Swettenham (1893), Sungai Perak's passage toward the wharf had good lighting, and therefore, became the stopover attraction for the trade ship from Singapore and Penang every day. The majority of the merchant's vessels that moored in Teluk Anson carried food supplies, tin ores, rubber, and the copra (Annual Report of Social and Economic Progress, 1947).

Teluk Anson in particular, and Lower Perak in general, pioneered the important role as one of the main wharf towns in the Federated Malay States alongside Port Weld and Port Swettenham. This was the outcome of a development plan constructed by Archibald Anson (Handbook of the Federated Malay States, 1902). Plus, Teluk Anson wharf used to be said to operate as the main wharf in Perak. This wharf served as the stopover for a ship from Straits Steamship Company that loaded with cargos from three wharves which were Teluk Anson, Malacca, and Singapore (Government Secretary 2471/91, 1891). Ship from Straits Steamship Company originated from Singapore operated every day and set off from Singapore to Teluk Anson and returned back to Malacca. This company was the dominant shipping company in trades around Malaya including Teluk Anson wharf (Ooi, 1963).

The construction of a new town in Teluk Malunting was nearing its completion before 1881 . However, afterward, Teluk Malunting was known as Teluk Anson in conjunction with General Archibald Anson's name who was responsible for drawing the first plan of Teluk Anson town. Teluk Anson wharf situated in Denison Road once served as a stopover for the ship from Straits Steamship Company that was loaded with cargos from three wharves which were Teluk Anson, Malacca, and Singapore (Government Secretary 2471/91, 1891). The ship that originated from Singapore operated on a daily basis and set off from Singapore wharf to Teluk Anson and returned back to Malacca afterward. Straits Steamship Company was a dominant 
shipping company in trades around waters of Tanah Melayu including Teluk Anson wharf (Ooi, 1963). It was established on 20th January 1890 and once used the name 'The Straits Navigation Company' (Samsudin et al, 2011). Since the 1890s, ships from the company began to moor in Teluk Anson and sailed to Port Swettenham and Singapore. Apart from conducting cargo service or goods transportation, ship from this company also operated to carry passengers to Singapore wharf with $\$ 12$ charge for first-class passengers, $\$ 6$ for second class, and $\$ 3$ for those going on the deck (Government Secretary 2471/91, 1891). The public used this marine transport as one of the communication network alternatives apart from the railways or roads, especially when heading to Selangor, Malacca, and Singapore.

In 1891, Straits Steamship Company received a contract to carry equipment for Kinta Valley Railway construction from Europe. This equipment was delivered to contractor in Singapore and directly sent to Teluk Anson wharf. The government or Federated Malay States Railway was responsible for preparing steam-winch to transport the equipment with a capacity of 2.5 tonnes or $2268 \mathrm{~kg}$ from the ship. Steam-winch was a machine that consumed steam energy and rotated for lifting heavy loads. Every $28 \mathrm{lbs}$ of items carried were charged with 40 cents and items exceeding this value but less than $56 \mathrm{lbs}$ would be charged with 75 cents. Ship of Straits Steamship Company was allowed to moor in Teluk Anson wharf if repair work of the ship was necessary for at least a week.

In 1901, Teluk Anson wharf suffered from erosion that occurred at its estuary. To prevent the problem from escalating to worse, the jetty was then moved to a safer location and suitable for the development of a town. The new wharf site was situated four-kilometer along Batak Rabit street (Khoo, 1995). Together with the new wharf, other facilities and infrastructure were also built. One of them was the railway from Teluk Anson station to the new jetty site. Roads were also built to facilitate the trader's and locals' journey to the jetty. The Lack of stopover for British officers led to the construction of a new rest-house. The rest house built was equipped with eight bedrooms, and two of the rooms were reserved Teluk Anson required an estimated $\$ 17,200$ and its construction began in 1913 (High Commissioner Officer 532/1912, 1912). Such initiative done showed the significance of Teluk Anson which used to be the attention of foreign/external officers and visitors due to the presence of farms cultivated around this district.

Marine transportation activity was actively performed in Teluk Anson during the British colonial era. Around 1946, maintenance of the jetty in Teluk Anson was conducted by Public Work Department. One of the trade activities carried out here was carrying 248 tonnes of rice on the 1st December 1945 and 260 tonnes of rubber on 4 December (in the same year?) to be carried to Penang (Marine 5/45, 1945). Rubber was one of the main goods transported through delivery service in Teluk Anson wharf (High Commissioner Office 1442/1915, 1915). In 1915, New York was one of the rubber export destinations via shipping service at which the journey began from Teluk Anson wharf. Delivery of the rubber in 1915 had received approval from Rubber Export Committee to be sent to the appointed location. Apart from that, a shed measured $132^{\prime} \times 48^{\prime} 6^{\prime \prime}$ was built nearby to the wharf as one of the public waiting for a place for the arrival of ships or boats. A new jetty structure together with two bridges to embark on was build as well. 700 meter-long road from the wharf area was paved to facilitate vehicle passage and also unloading task from the vehicle to the wharf. These upgraded new facilities had subsequently led to the increment in trade activity in the wharf area, and also trade ship stopover for both goods transportation and passenger boat service. The usage of light in a lighthouse that initially used oil/petrol had been converted to 
automatic lighting which was more appropriate with the busier wharf's condition due to the trade ship's stopover.

Other than the trades, boat rental service was also implemented by the traders and sailor that owned a ship (Perak Administration Report, 1930). According to the record in Perak Administration Report 1930, 48 engine boats passed through Sungai Bernam and Sungai Perak would stop in Teluk Anson wharf. Within the same year, water transportation service using ships communicating Bangkok to Teluk Anson was introduced by Hung Phong Company of Bangkok. Every fortnight, Teluk Anson wharf would receive rice exported from Bangkok via the company's ship. This trade relationship between Perak and Bangkok existed since colonial showed that British administration concerned on good relationship and trades with regional/neighboring countries.

Teluk Anson wharf role development had triggered the development of transportation networks. And this transportation network had become one of the development factors in Teluk Anson town. Raw material demands encouraged the commodity export and indirectly, affairs in Teluk Anson became the attraction/interest/attention/focus of trade or commerce ships from all Malay states and also foreign countries. The importance of Teluk Anson wharf role was said to be a symbol of a new economic shift for Lower Perak district generally, and Teluk Anson town in particular (Lim, 1978).

Infrastructures available in the Teluk Anson wharf region had caused it to become an important attraction in the Federated Malay States during the early of its opening until the second world war. Trade activities in the wharf also contributed to the urbanization process in Teluk Anson (Babulal \& Ariffin, 2019). In addition, the existence of this wharf was closely related to the construction of the second railway in Tanah Melayu which was the route from Tapah to Teluk Anson. Thus, Teluk Anson was a very significant wharf in Perak during British colonial and became the contributor to the development of Teluk Anson town.

\section{The Development of Railway System}

Teluk Anson railway network began following Kinta Valley railway construction in May 1891 (Hanson, 1902). The route construction linked a number of train stations which were in Teluk Anson and coursing through Batang Batang to Ipoh. The main train station terminal in Teluk Anson was situated in Denison Road, nearby the entrance of the canal. Denison's name was actually from the name of Noel Denison, who served as the superintendent or ruler of Lower Perak (Khoo, 1995).

Branch lines from Teluk Anson to Tapah Road measured 16 miles apart. The change in the land transportation system had somewhat affected the small boat services which majorly involved the Malays. After the establishment of train service, traders and locals had options on how to transport their goods either via small boat or train services (Khoo, 1995).

Throughout new station and dock/jetty construction in Teluk Anson starting from 1907, other infrastructures and facilities were built as well. This included the railway from Teluk Anson to the new dock/jetty site. Roads were built along to ease up the journey to the dock/jetty. And, cargo storage place was equipped with a roof to protect the goods before being embarked into the ship. 700 yards road to the station was built along as one of the wharf's infrastructure improvement processes. $\$ 70,000$ budget had been granted to Teluk Anson's management for such purpose. 


\section{Commercial Agriculture in Lower Perak}

Nova Scotia Estate which was famously known for sugar manufacturing around the 1890 s also made Teluk Anson become an agriculture-based town. Nova Scotia Estate was one of the main sugarcane farm companies in Lower Perak (Supplement to Perak Government Gazette, 1905). Sugarcane yields of this company had to monopolize or dominating the demands and sale of sugarcane in whole Perak.

In 1920, there was the expansion of sugarcane farm up to 20,000 acres after it received approval from Lower Perak District Officer (Selangor Secretariat 3068/1921, 1921). This farm in Teluk Anson was cultivated by laborers paid by Sir John Ramsden whose role was the head of structure planning of Nova Scotia Estate. The increment in the number of Europeans served in the farming sector in Teluk Anson led to the construction of luxurious residences featuring the west, and also recreational facilities nearby (Lees, 2017). One of these was the cricket field and tennis court. Figure 1 below showed the plan off the Nova Scotia Estate in 1910.

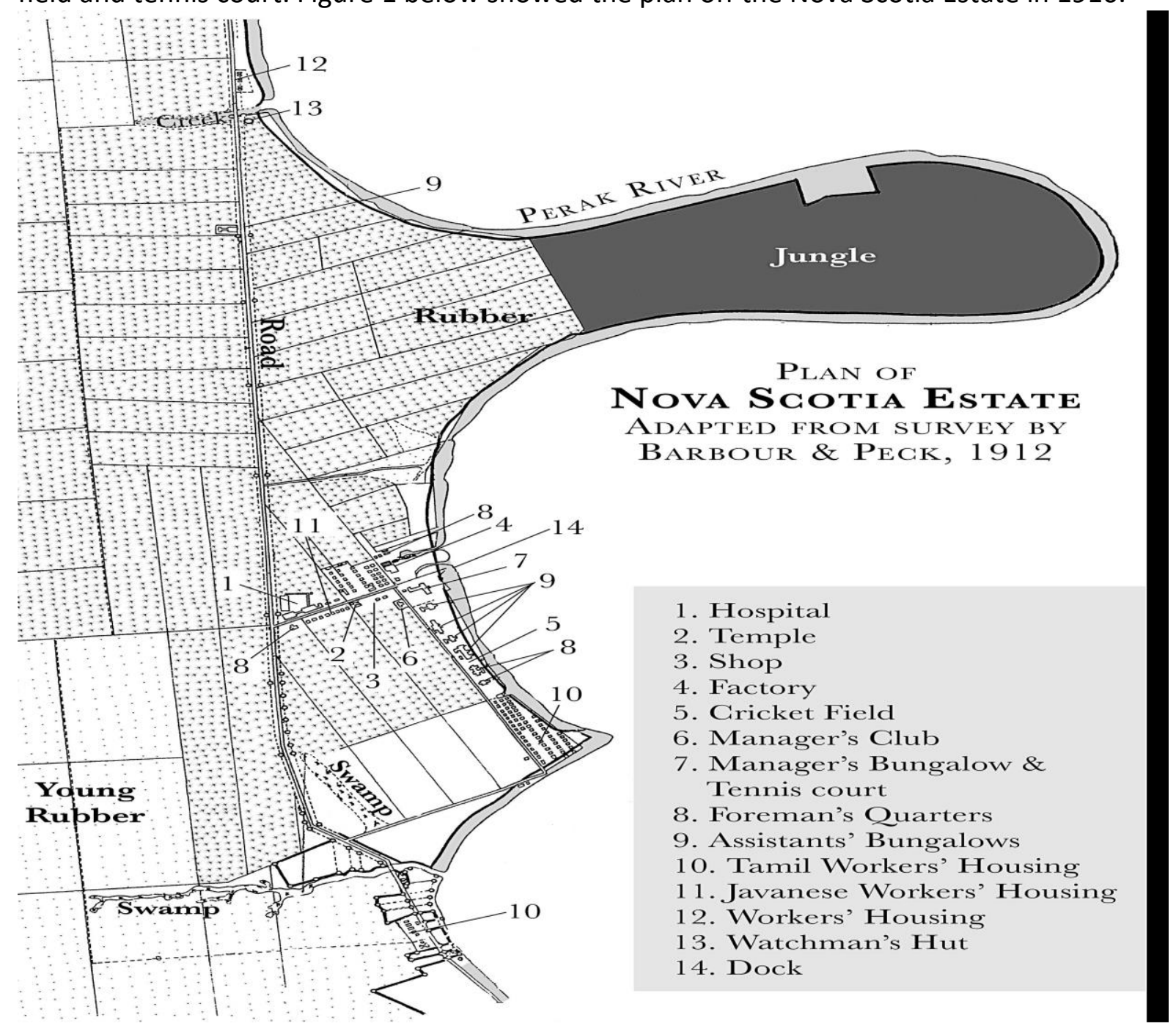

Figure 1: Nova Scotia Estate Plan in Teluk Anson (Lees, 2017)

To facilitate the land ownership process by peasants that cultivated sugarcane, 20,000 acres of land was extended particularly by Lower Perak district officer, specifically meant for sugarcane cultivation. Due to the increment of sugarcane crops in Teluk Anson, the British colonial administration then gazetted terms and conditions for the opening of sugarcane farms by the respective company. Following were the conditions applied for the land 
application for sugarcane farm opening that must be obeyed by all involved companies (Selangor Secretariat 3068/1921, 1921):

1. Land ownership application for sugarcane cultivation must lease for 14 years with the right of renewing for 14 years for each acre of crops.

2. No premium or charges would be given.

3. Free land rent for the first three years of cultivating activity and afterward, fees would be charged with $\$ 1$ for each acre.

4. The crop condition must be determined in section 3 The Country Land in Cultivation Enactment 1914.

5. Export tax would not be applied against sugar production that had been processed from 1st January 1922 till 31st December 1926. Once the period ends, $2.5 \%$ of tax from the total yields would be charged starting 1st January 1927 until 31 December 1939

Other than sugarcane cultivation, Teluk Anson also had a surveillance center for coconut cultivation in the Lower Perak district. The sub-inspector was responsible for surveying the coconut cultivation in that district (Perak Government Gazette, 1906).

\section{Irrigation System Infrastructure Facility}

Roads and drainage system maintenance was among the infrastructure improvement done in Teluk Anson (Perak Annual Report, 1884). Teluk Anson town development also concurrent with the establishment of an irrigation system for cultivation, mainly the paddy. Sungai Manik area was the region that possessed the potential for paddy cultivation as it had a suitable soil structure. In an attempt to encourage paddy cultivation in Teluk Anson, Sungai Manik Irrigation Scheme was introduced. Through this scheme, road construction was prioritized and its construction to Sungai Manik was one of the communication facilities for the locals to carry out their economic activity (Malayan Union 3444/1947, 1947).

To execute the irrigation system construction, a huge number of laborers were required, hence, 4000 labors were involved (Malayan Union 3444/1947, 1947). Many laborers were needed for deforestation to continue building the irrigation of Sungai Manik. This construction created new settlements lived by these laborers where temporary share house was built for them throughout the irrigation system building process. This house could accommodate about 50 occupants. Here, these laborers were categorized as founders or early residents in the area as they were involved in clearing the forest for the sake of developing the Sungai Manik area. However, in encouraging the construction of permanent settlements around the Sungai Manik irrigation area, basic facilities for the residents were established during the British administration in 1947 (Malayan Union 3444/1947, 1947).

\section{Conclusion}

Overall, the existing infrastructure available in Teluk Anson caused the wharf to become the attraction as the main wharf in the Federated Malay States. Thus, it stimulated development in Lower Perak district into a distinguishable town in Perak. Teluk Anson wharf establishment was indeed closely related to the second railway construction in Tanah Melayu which linked Tapah to Teluk Anson, besides other infrastructure development. Therefore, this study showed that town development was the impact of the economy based on the wharf which also encouraged the expansion of transportation networks and commercial agriculture in Teluk Anson. 


\section{Acknowledgment}

This study is under the provision of external research approved by the Research Management \& Innovation Centre (RMIC) of Sultan Idris Education University. (Research Code: 2019-0234107-29). Special thanks and high appreciation to Famous Pacific Shipping Sdn Bhd for the support and sponsorship of a research grant.

\section{References}

\section{Annual Report and Colonial File}

Annual Report of Social and Economic Progress, 1947

Government Secretary 2471/91, Forward Copy of a Entered into by This Government with The Straits Steam Ship Company, 1891

Handbook of Federated Malay States. (1902).

HCO 1442/1915, Rubber Shipment 1915

HCO 532/1912, Proposed Building of a New Rest House at Teluk Anson

Malayan Union 3444/1947, Development of Colonisation Areas for Paddy Cultivation

Marine 5/45, Harbour Master Office Teluk Anson.

Perak Administration Report, 1930

Perak Annual Report, 1884

Perak Government Gazette. (1906). Department of Agriculture. Report of The Inspector of Coconut Plantation For The Year 1906.

Perak Secretariat 1495/1908, Annual Report on The Federated Malay State Railways, 1907.

Perak Secretariat 3277/1948, Name Of Town And Village In English

Selangor Secretariat 3068/1921, Cultivation Of Sugar Cane In Malaya.

Supplement to Perak Government Gazette, 1905

\section{References}

Babulal, B., \& Ariffin, K. (2019). The Importance of Teluk Anson Wharf as Transit Centre of Merchant Vessel, 1882-1941. International Journal of Heritage, Art, and Multimedia, 2(5), 72-79

Bakar, M. D. A. (1996). Perancangan Pembangunan Bandar Baru: Kajian Kes Bandar Baru Pasir Gudang, Unpublished Master Thesis, Universiti Sains Malaysia.

Swettenham, F. A. (1893). About Perak. Singapore: The Straits Times.

Hanson, C. R. (1902). Federated Malay States Railways, Perak and Provinces Wellesly

Hirchman, C., \& Yeoh, S. P. (1979). Ethnic patterns of urbanization in Peninsular Malaysia, 1947 1970, Southeast Asian Journal of Social Science, 7(1/2), 1-19

Hussin, N. (2002). A Tale of Two Port-Towns in the Straits of Melaka: Dutch Melaka and English Penang. Journal of Malayan Branch of the Royal Asiatic Society, 75(2).

Khoo, K. K. (1995). Teluk Anson: 1882-1941:Port, Agriculture and Erosion. Journal ofMalayan Branch of the Royal Asiatic Society, 68(2), 33-52

Lees, L. H. (2017). Planting empire, cultivating subjects: British Malaya, 17861941.Cambridge: Cambridge University Press.

Lim, H. K. (1978). The Evolution of Urban Sistem in Malaya. Kuala Lumpur: PenerbitUniversiti Malaya

Ooi, J. B. (1963). Land, People, and Economy in Malaya. London: Longmans, Green and Co. Ltd. 
Samsudin, M., Manaf, A. A., \& Shaharuddin, S. (2011). The development of marine transport around the east coast of Malaya from an early age to the period of the British administration. Journal of Tropical Marine Ecosystem, 1(2).

Wayte, M. E. (1959). Port Weld. Journal of the Malayan Branch of the Royal Asiatic Society. 32(1), 154-167 